\title{
Effects of different nitrogen doses and cultivars on fermentation quality and nutritive value of Italian ryegrass (Lolium multiflorum Lam.) silages
}

\author{
Ibrahim Ertekin ${ }^{1, \star}$, Ibrahim Atis ${ }^{1}$, Yusuf Ziya Aygun ${ }^{1}$, Saban Yilmaz ${ }^{1}$, and Mustafa Kizilsimsek ${ }^{2}$
}

\footnotetext{
* Corresponding Author: Ibrahim Ertekin Tel: +90-545-259-0187,

Fax: +90-326-245-5832,

E-mail: ibrahimertekin@mku.edu.tr
}

${ }^{1}$ Department of Field Crops, Faculty of Agriculture, Hatay Mustafa Kemal University, Hatay 31060, Turkey

2 Deparment of Field Crops, Faculty of Agriculture, Kahramanmaras Sutcu Imam University, Kahramanmaraş 46040, Turkey

\section{ORCID}

Ibrahim Ertekin

https://orcid.org/0000-0003-1393-8084 Ibrahim Atis

https://orcid.org/0000-0002-0510-9625 Yusuf Ziya Aygun

https://orcid.org/0000-0001-9842-006X

Saban Yilmaz

https://orcid.org/0000-0003-2558-5802 Mustafa Kizilsimsek

https://orcid.org/0000-0002-0295-0603

Submitted Mar 12, 2021; Revised Apr 16, 2021; Accepted May 23, 2021
Objective: The fermentation profile and silage quality of 3 Italian ryegrass (Lolium multiflorum Lam.) cultivars (cvs. Devis, Hellen, and Trinova) treated with 5 nitrogen doses $(0,50,100$, 150 , and $200 \mathrm{~kg} / \mathrm{ha}$ ) were evaluated.

Methods: The experiment was laid out in split plot in randomized complete block design with three replications. Annual ryegrass cultivars used in this study have been commonly grown in Turkey. Nitrogen doses were set in main plot and cultivars in split plot in the field. Plants were harvested at full-flowering stage with dry matter content about $220 \mathrm{~g} / \mathrm{kg}$ for first cutting and $260 \mathrm{~g} / \mathrm{kg}$ for second cutting. Harvested plants were chopped theoretically into 2 to $3 \mathrm{~cm}$ lengths for ensiling. Chopped fresh materials were ensilaged by compressing in $2 \mathrm{~L}$ plastic jars about $3 \pm 0.1 \mathrm{~kg}$.

Results: Effects of $\mathrm{N}$ doses on dry matter, neutral detergent fiber, acid detergent fiber, dry matter digestibility, relative feed value, crude protein, $\mathrm{pH}$, ammonia nitrogen, lactic acid, acetic acid, and lactic acid/acetic acid were statistically significant while water soluble carbohydrate, ash and organic matter were not statistically different. Ammonia nitrogen, crude protein, ash, organic matter, lactic acid, and lactic acid/acetic acid were affected by cultivars, but the other parameters were not. Increasing nitrogen applications positively affected the chemical composition of annual ryegrass silage. The significant increase in protein content was remarkable, however, silage fermentation properties were adversely affected by the increasing nitrogen dose.

Conclusion: It can be recommended $150 \mathrm{~kg} / \mathrm{ha}$ nitrogen dose for annual ryegrass harvested at full blooming stage. Even though the silage fermentation properties of the used cultivars were similar, cv. Devis gave better results than the others in terms of silage $\mathrm{pH}$ and relative feed value.

Keywords: Annual Ryegrass; Fermentation Quality; Nitrogen Fertilizer; Nutritive Value; Silage

\section{INTRODUCTION}

Forage crop conservation is a significant subject in agricultural practices. One of the most common used techniques is ensiling method. Ensiling is based on natural fermentation in which the epiphytic lactic acid bacteria convert sugars into lactic acid under anaerobic conditions. Annual ryegrass with high forage quality is an important forage crop for animal feeding. This plant has been widely cultivated throughout temperate and tropical or subtropical regions of the world $[1,2]$. Also, the plant has been ensilaged in many countries and commonly used as a major silage crop.

Fertilization is the most effective treatment on yield and quality of plants and results of this practice are immediately ascertainable [3]. In addition, especially nitrogen fertilization 
increases quality of forage grasses significantly [4,5]. Many studies including nitrogen applications were carried out about forage yield and quality of Italian ryegrass. Even low nitrogen doses provide an increase in protein content and forage yield compared to the non-fertilizer treatments in Italian ryegrass. A rise in protein ratio is achieved after a certain nitrogen dose, but no increase in forage yield is observed [6]. Kunelius and Boswall [7] reported that the $\mathrm{N}$ fertilizer doses of 0.35 to $0.50 \mathrm{~kg} / \mathrm{ha}$ with sowing, 0.35 to $0.50 \mathrm{~kg} / \mathrm{ha}$ after first cutting and 0.65 to $0.80 \mathrm{~kg} / \mathrm{ha}$ after second cutting were appropriate in annual ryegrass cultivation. Thereby, high forage yield and quality from Italian ryegrass can be obtained. It was determined that increasing the nitrogen fertilizer doses increased chlorophyll content of Italian ryegrass [8]. In addition, the highest crude protein (CP) and dry matter (DM) yield in Italian ryegrass were obtained from $120 \mathrm{~kg} / \mathrm{ha}$ nitrogen treatment [9].

Many researchers reported that the plant yield and quality improved with the increasing nitrogen doses in Italian ryegrass cultivation. However, there is limited knowledge on the monitoring of the change in silage quality and ensilage performance of Italian ryegrass grown with increasing nitrogen doses. The goals of the current study were therefore to investigate the effects of different $\mathrm{N}$ treatments on silage fermentation quality and nutritive value of various Italian ryegrass cultivars.

\section{MATERIALS AND METHODS}

\section{Planting, growing and silage preparation of annual ryegrasses}

This study was carried out at Hatay Mustafa Kemal University in Turkey. Three different annual ryegrass (ARG) cultivars and nitrogen fertilizer were used as the material in this research. The experiment was laid out in split plot in randomized completed block design with three replications. ARG cultivars used in study have been commonly grown in Turkey. cvs Devis, Hellen and Trinova were obtained from Mutlu Seed, Alfa Seed and Semillas Fito Agriculture companies from Turkey. 0 (control), 50, 100, 150, and $200 \mathrm{~kg} / \mathrm{ha}$ of nitrogen doses were set in main plot in experiment design and the ARG cultivars were sown in split plot. Fertilizer doses were applied to the soil surface in two parts, before planting and after first harvesting. ARG cultivars were planted in eight rows for each plot. Spaces of among the main plots, split plots and blocks were $1 \mathrm{~m}, 0.5 \mathrm{~m}$ and $3 \mathrm{~m}$, respectively. ARG seeds were sown $50 \mathrm{~kg} / \mathrm{ha}$. ARG cultivars were planted in November 2017 with the first cutting in April 2018 and the second cutting in June 2018. Plants were harvested in full-flowering stage with DM content about $220 \mathrm{~g} / \mathrm{kg}$ for first cutting and $260 \mathrm{~g} / \mathrm{kg}$ for second cutting. Harvested fresh samples were chopped (CAN SP255, CANTEK MAKINE, Sinop, Turkey) theoretically without wilting into 2 to $3 \mathrm{~cm}$ lengths to ensile. It was reserved about $500 \pm 20 \mathrm{~g}$ to determine the initial chemical compositions (Table 1) of materials from chopped plants. These samples were dried in an oven-drying cabinet at $65^{\circ} \mathrm{C}$ for 48 hours. Chopped fresh materials obtained from each plot were ensiled in $2 \mathrm{~L}$ plastic jars about $3 \pm 0.1 \mathrm{~kg}$ with 3 replications. Jars were stored at $25^{\circ} \mathrm{C}$ in dark conditions during the fermentation stage.

\section{Chemical analyzes and determination of nutritive value of silages}

All silages were opened after 90 days' fermentation. A sam-

Table 1. Chemical composition and $\mathrm{pH}$ value of Italian ryegrass in response to nitrogen, cultivar and cutting rank

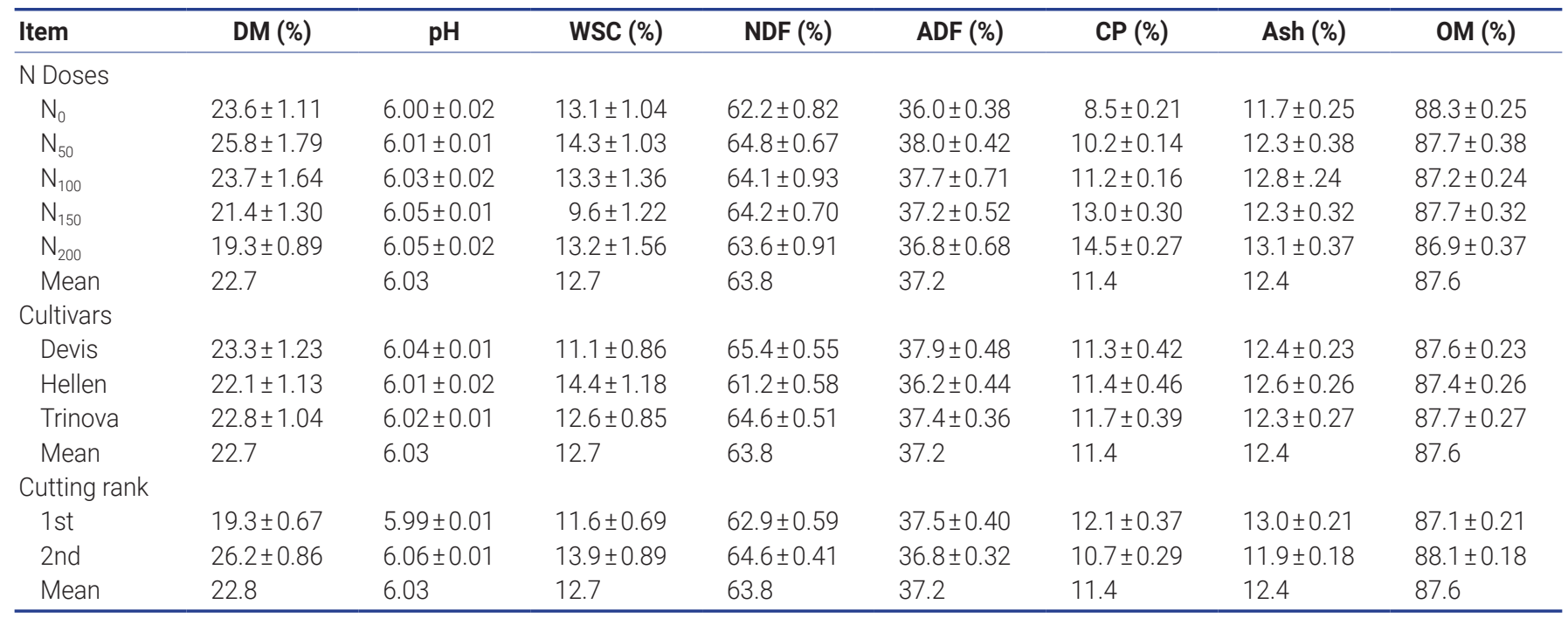

$\mathrm{DM}$, dry matter; $\mathrm{pH}$, power of hydrogen; WSC, water soluble carbohydrate; NDF, neutral detergent fiber; ADF, acid detergent fiber; CP, crude protein; OM, organic matter 
ple of $20 \mathrm{~g}$ was taken from each silage and mixed with 180 $\mathrm{mL}$ of Ringer's solution with a hand blender for 90 seconds at high speed and then filtered with Whatman 55 paper to obtain water extract [10]. $\mathrm{pH}$ measurements, water soluble carbohydrate (WSC), lactic acid (LA) and acetic acid (AA) and ammonia nitrogen $\left(\mathrm{NH}_{3}-\mathrm{N}\right)$ content were analyzed on silage water extract. $\mathrm{pH}$ measurements of silages were determined at the temperature of $25^{\circ} \mathrm{C}$ via $\mathrm{pH}$ meter (INOLAB, 8F93, Weilheim, Germany). The WSC contents of silages were analyzed according to the phenol-sulfuric acid calorimetric method reported by Dubois et al [11]. Samples of $300 \pm 20 \mathrm{~g}$ from silages were dried in the oven-drying at $65^{\circ} \mathrm{C}$ for 48 hours, ground in mill with $1 \mathrm{~mm}$ sieve diameter and made ready chemical analysis. Total $\mathrm{N}$ was determined according to method of $7.022 \mathrm{AOAC}$ [12]. The CP contents were calculated with 6.25 coefficient unit. Ash contents were determined in an ash furnace by burning at $550^{\circ} \mathrm{C}$ for 4 hours. Cell wall contents such as neutral detergent fiber (NDF) and acid detergent fiber (ADF) were analyzed with ANKOM Fiber Analyzer (ANKOM Technology Corp., Fairport, NY, USA) according to the method described by AOAC [13]. Acid detergent lignin $(\mathrm{ADL})$ analysis was made according to method reported by Robertson and Van Soest [14]. $\mathrm{NH}_{3}-\mathrm{N}$ contents of silages were determined with Kjehdahl distillation and titration apparatus according to method of Blümmel et al [15]. The LA and AA contents of silages were analyzed by using high performance liquid chromatography (HPLC, Shi-madzu GC-2010, Kyoto, Japan) at $42^{\circ} \mathrm{C}, 0.6 \mathrm{~mL} / \mathrm{min}$ flow rate and by using refractive index detector described by Quiros et al [16] after the sample cleaning procedure. DM digestibility (DMD), DM intake (DMI) and relative feed value (RFV) properties of silages were calculated with the following formulas described by Van Dyke and Anderson [17].

$$
\begin{aligned}
& \operatorname{DMD}(\%)=88.9-(0.779 \times \mathrm{ADF} \%) \\
& \operatorname{DMI}(\%)=120 / \mathrm{NDF} \% \\
& \text { RFV }=\text { DMD } \% \times \text { DMI } \% \times 0.775
\end{aligned}
$$

\section{Statistical analyzes}

The statistical calculations of the data obtained this study were performed by split-split plot in randomized complete design using the statistical program of MSTAT-C. The general linear model was used to determine the differences among the means of investigated features in this study. Duncan multiple range test $(\mathrm{p}<0.05)$ was used to compare ARG cultivars and nitrogen doses and cutting ranks. In this study, interaction effects of ARG cultivars, nitrogen doses and cutting ranks used as experimental factors are not presented.

\section{RESULTS}

Fermentation features, chemical compositions and nutritive value of silages

The DM contents of annual ryegrass silages were decreased with increasing $\mathrm{N}$ doses. DM contents of silages were $23.0 \%$, $25.3 \%, 23.2 \%, 20.8 \%$, and $18.9 \%$ for the $0,50,100,150$, and $200 \mathrm{~kg} /$ ha $\mathrm{N}$ doses $\left(\mathrm{N}_{0}, \mathrm{~N}_{50}, \mathrm{~N}_{100}, \mathrm{~N}_{150}\right.$, and $\left.\mathrm{N}_{200}\right)$ respectively (Table 2). The DM contents of cultivars were not different. The effect of cutting rank on DM content was significant. The DM content obtained in the first cutting (18.8\%) was lower than obtained in the second cutting (25.7\%).

The $\mathrm{pH}$ values of annual ryegrass silages were significantly influenced by $\mathrm{N}$ dose. The lowest $\mathrm{pH}$ value was determined in the control treatment $\left(\mathrm{N}_{0}\right)$ without nitrogen application. The $\mathrm{pH}$ values of $\mathrm{N}_{50}, \mathrm{~N}_{100}$ and $\mathrm{N}_{150}$ treatments were statistically similar while the $\mathrm{pH}$ value of $\mathrm{N}_{200}$ treatment was significantly higher than others. No statistically significant difference was observed among the $\mathrm{pH}$ values of the cultivars. The effects of cutting ranks were significant in terms of the $\mathrm{pH}$ values, which were 4.79 and 4.57 for first and second cutting, respectively (Table 2).

$\mathrm{NH}_{3}-\mathrm{N}$ contents were influenced $(\mathrm{p}<0.01)$ by all experimental factors (Table 2). $\mathrm{NH}_{3}-\mathrm{N}$ contents of silages tended to increase with increasing $\mathrm{N}$ doses. However, the $\mathrm{NH}_{3}-\mathrm{N}$ contents determined in $\mathrm{N}_{50}$ and $\mathrm{N}_{100}$ nitrogen applications were not different from the control $\left(\mathrm{N}_{0}\right)$. The $\mathrm{NH}_{3}-\mathrm{N}$ content increased significantly as the nitrogen dose increased to $\mathrm{N}_{150}$ $\mathrm{kg} / \mathrm{ha}$. The $\mathrm{NH}_{3}-\mathrm{N}$ content determined in $\mathrm{N}_{200}$ nitrogen application was higher than all other applications. The $\mathrm{NH}_{3}-\mathrm{N}$ contents ranged from $6.13 \%$ to $6.52 \%$ among the annual ryegrass cultivars. While cv. Devis and cv. Hellen had similar $\mathrm{NH}_{3}-\mathrm{N}$ content, $\mathrm{NH}_{3}-\mathrm{N}$ content of $\mathrm{cv}$. Trinova was higher $(\mathrm{p}<0.01)$ than the others. $\mathrm{NH}_{3}-\mathrm{N}$ content determined as the first cutting $(6.76 \%)$ was higher than determined at the second cutting (5.80\%).

The effects of cutting rank were significant in terms of WSC while $\mathrm{N}$ doses and cultivars were insignificant (Table 2). WSC values were ranged among $4.30 \%$ and $6.72 \%$ depend on $\mathrm{N}$ doses. But these differences in values were statistically insignificant. WSC values recorded for cv. Devis, cv. Hellen and cv. Trinova were 5.92\%, 4.88\%, and 5.13\%, respectively. WSC determined at the first cutting (6.52\%) was higher ( $\mathrm{p}<$ 0.01 ) than determined at the second cutting $(4.10 \%)$.

The increase in nitrogen doses caused a decrease in NDF contents. NDF contents of silages were $66.4 \%, 66.9 \%, 66.0 \%$, $62.4 \%$, and $62.6 \%$ for $\mathrm{N}_{0}, \mathrm{~N}_{50}, \mathrm{~N}_{100}, \mathrm{~N}_{150}$, and $\mathrm{N}_{200}$, respectively (Table 2). NDF contents of $\mathrm{N}_{0}$ and $\mathrm{N}_{50}$ were higher $(\mathrm{p}<0.01)$ than those of $\mathrm{N}_{150}$ and $\mathrm{N}_{200}$. The NDF content of $\mathrm{N}_{100}$ was similar to all other $\mathrm{N}$ applications. NDF contents of cultivars varied between $64.0 \%$ and $65.2 \%$, but these differences were not significant. NDF percentage obtained at the first cut was 
Table 2. Effects of $\mathrm{N}$ doses, cultivars and cutting rank on silage dry matter (DM), $\mathrm{pH}, \mathrm{NH}_{3}-\mathrm{N}$ and some chemical compositions

\begin{tabular}{|c|c|c|c|c|c|c|}
\hline Items & DM (\%) & $\mathrm{pH}$ & $\mathrm{NH}_{3}-\mathbf{N}(\%$ Total $\mathbf{N})$ & WSC (\% DM) & NDF (\% DM) & ADF (\% DM) \\
\hline \multicolumn{7}{|l|}{ N Doses } \\
\hline $\mathrm{N}_{0}$ & $23.0 \pm 1.07^{\mathrm{ab}}$ & $4.47 \pm 0.05^{c}$ & $5.36 \pm 0.23^{c}$ & $4.30 \pm 0.56$ & $66.4 \pm 0.71^{a}$ & $41.5 \pm 0.86^{a}$ \\
\hline $\mathrm{N}_{100}$ & $23.2 \pm 1.62^{\mathrm{ab}}$ & $4.66 \pm 0.06^{b}$ & $5.53 \pm 0.13^{c}$ & $5.82 \pm 0.87$ & $66.0 \pm 0.78^{\mathrm{ab}}$ & $40.3 \pm 0.92^{\mathrm{ab}}$ \\
\hline $\mathrm{N}_{150}$ & $20.8 \pm 1.30^{\mathrm{bc}}$ & $4.71 \pm 0.04^{b}$ & $6.55 \pm 0.10^{b}$ & $4.32 \pm 0.53$ & $62.4 \pm 0.78^{b}$ & $38.5 \pm 0.64^{b}$ \\
\hline $\mathrm{N}_{200}$ & $18.9 \pm 0.88^{c}$ & $4.96 \pm 0.05^{\mathrm{a}}$ & $8.47 \pm 0.23^{\mathrm{a}}$ & $6.72 \pm 0.61$ & $62.6 \pm 0.76^{b}$ & $38.4 \pm 0.44^{b}$ \\
\hline \multicolumn{7}{|l|}{ Cultivars } \\
\hline Devis & $21.6 \pm 1.24$ & $4.72 \pm 0.06$ & $6.13 \pm 0.30^{b}$ & $5.92 \pm 0.62$ & $64.0 \pm 0.85$ & $40.1 \pm 0.69$ \\
\hline Hellen & $22.4 \pm 1.11$ & $4.67 \pm 0.04$ & $6.21 \pm 0.20^{b}$ & $4.88 \pm 0.51$ & $65.0 \pm 0.71$ & $40.0 \pm 0.71$ \\
\hline Trinova & $22.7 \pm 1.02$ & $4.65 \pm 0.04$ & $6.52 \pm 0.23^{\mathrm{a}}$ & $5.13 \pm 0.51$ & $65.2 \pm 0.47$ & $40.4 \pm 0.55$ \\
\hline Mean & 22.2 & 4.68 & 6.28 & 5.31 & 64.7 & 40.2 \\
\hline \multicolumn{7}{|c|}{ Cutting rank } \\
\hline Mean & 22.2 & 4.68 & 6.28 & 5.31 & 64.7 & 39.9 \\
\hline p-value & $\star \star$ & $\star \star$ & $\star \star$ & $\star \star$ & * & ns \\
\hline
\end{tabular}

DM, dry matter; $\mathrm{pH}$, power of hydrogen; $\mathrm{NH}_{3}-\mathrm{N}$, ammonia nitrogen; $\mathrm{WSC}$, water soluble carbohydrate; NDF, neutral detergent fiber; ADF, acid detergent fiber; ns, non-significant.

${ }^{a-c}$ Mean values with different superscripts have significant differences. ${ }^{\star *} p<0.01 ;{ }^{*} p<0.05$.

significantly lower $(\mathrm{p}<0.05)$ than that obtained on the second cut (63.8\% and $65.6 \%$, respectively).

The effects of $\mathrm{N}$ doses were significant in terms of the ADF content. The change of ADF contents depending on the nitrogen doses showed a similar situation with the NDF contents. ADF contents ranged from $38.4 \%$ to $42.4 \%$ depending on $\mathrm{N}$ doses. The effects on ADF contents of cultivars and cutting ranks were not significant (Table 2). The ADF contents of the three cultivars were similar. ADF values determined in the first and second cuttings were also not different from each other.

The CP contents were significantly influenced by all experimental factors. A continuous increase in the $\mathrm{CP}$ content due to increased $\mathrm{N}$ doses was observed. The $\mathrm{CP}$ content values determined for each nitrogen dose application were significantly different. The CP contents of silages were $7.0 \%$, $8.5 \%, 11.1 \%, 12.4 \%$, and $13.0 \%$ for $\mathrm{N}_{0}, \mathrm{~N}_{50}, \mathrm{~N}_{100}, \mathrm{~N}_{150}$, and $\mathrm{N}_{200}$, respectively (Table 3). Increasing the dose of nitrogen from $\mathrm{N}_{0}$ to $\mathrm{N}_{200} \mathrm{~kg} / \mathrm{ha}$ resulted in an increase in CP content. The $\mathrm{CP}$ content of $\mathrm{cv}$. Hellen was higher than other cultivars. The CP contents of cv. Devis and cv. Trinova were statistically similar (Table 3). The CP content of silage made at the first cutting $(10.1 \%)$ was lower $(\mathrm{p}<0.001)$ than that of silage made at the second cutting (10.7\%).

The effects of cultivars and cutting rank were significant in terms of the ash content while $\mathrm{N}$ doses had no significant effect (Table 3). The ash contents of silages were ranged from $11.7 \%$ to $13.1 \%$ depending on $\mathrm{N}$ doses. The highest ash con- tent was obtained from cv. Devis. The ash contents of cv. Hellen and cv. Trinova were statistically similar. The ash content determined at the first cutting (13.8\%) was higher than determined at the second cutting (12.5\%).

Nitrogen had no significant effect on organic matter $(\mathrm{OM})$ (Table 3). The OM content of cv. Devis (86.3\%) was lower $(\mathrm{p}<0.01)$ than cvs. Hellen $(87.3 \%)$ and Trinova $(87.0 \%)$. The OM content of the first cutting was lower $(\mathrm{p}<0.01)$ than the OM content of the second cutting (86.3\%).

The effects of $\mathrm{N}$ doses on DMI, DMD, and RFV were significant $(\mathrm{p}<0.01)$ and parallel. All three characteristics tended to increase with increasing $\mathrm{N}$ doses (Table 3). DMD, DMI, and RFV values determined in $\mathrm{N}_{0}$ and $\mathrm{N}_{50}$ doses were lower $(\mathrm{p}<0.05)$ than those of $\mathrm{N}_{150}$ and $\mathrm{N}_{200}$ while $\mathrm{N}_{100}$ was intermediate. DMD, DMI, and RFV values of $\mathrm{N}_{100}$ was similar to all other $\mathrm{N}$ applications. Cultivar had no significant effect on DMD, DMI, and RFV. DMI was decreased $(p<0.05)$ at the second cut but no effects were noted on DMD or RFV. DMI value determined at the first cutting (1.9) was higher than determined at the second cutting (1.8).

A continuous decrease $(\mathrm{p}<0.01)$ in the LA content due to increased $\mathrm{N}$ was observed (Table 4). The highest LA content was obtained from control treatment $\left(\mathrm{N}_{0}\right)$ while the lowest LA content was obtained from $\mathrm{N}_{200}$ nitrogen treatment. LA content of $\mathrm{cv}$. Devis $(3.46 \% \mathrm{DM})$ was lower $(\mathrm{p}<0.01)$ than $\mathrm{cv}$. Hellen (3.64\% DM) and cv. Trinova (3.65\% DM). The LA was increased at the second cutting $(\mathrm{p}<0.01)$.

The trend of change of AA content depending on nitrogen 
Table 3. Effects of $\mathrm{N}$ doses, cultivars and cutting rank on silage some chemical compositions and nutritive value

\begin{tabular}{|c|c|c|c|c|c|c|}
\hline Items & CP (\% DM) & Ash (\% DM) & OM (\% DM) & DMD (\%) & DMI & RFV \\
\hline \multicolumn{7}{|l|}{ N Doses } \\
\hline NO & $7.0 \pm 0.16^{e}$ & $12.7 \pm 0.40$ & $87.3 \pm 0.40$ & $56.6 \pm 0.67^{b}$ & $1.8 \pm 0.02^{b}$ & $79.5 \pm 1.63^{b}$ \\
\hline N50 & $8.5 \pm 0.09^{d}$ & $13.1 \pm 0.33$ & $86.9 \pm 0.33$ & $55.9 \pm 0.66^{b}$ & $1.8 \pm 0.02^{b}$ & $78.1 \pm 1.88^{b}$ \\
\hline N100 & $11.1 \pm 0.17^{c}$ & $13.1 \pm 0.28$ & $86.9 \pm 0.28$ & $57.5 \pm 0.72^{\mathrm{ab}}$ & $1.9 \pm 0.02^{\mathrm{ab}}$ & $82.6 \pm 1.92^{\mathrm{ab}}$ \\
\hline N150 & $12.4 \pm 0.10^{b}$ & $13.4 \pm 0.29$ & $86.6 \pm 0.29$ & $58.9 \pm 0.50^{a}$ & $1.9 \pm 0.02^{\mathrm{a}}$ & $88.2 \pm 1.70^{\mathrm{a}}$ \\
\hline N200 & $13.0 \pm 0.17^{a}$ & $13.3 \pm 0.29$ & $86.7 \pm 0.29$ & $59.0 \pm 0.34^{a}$ & $1.9 \pm 0.02^{a}$ & $88.0 \pm 1.56^{a}$ \\
\hline Mean & 10.4 & 13.1 & 86.9 & 57.6 & 1.9 & 83.3 \\
\hline$p$-value & ** & ns & ns & * & * & * \\
\hline \multicolumn{7}{|l|}{ Cultivars } \\
\hline Devis & $10.3 \pm 0.40^{b}$ & $13.7 \pm 0.24^{a}$ & $86.3 \pm 0.24^{b}$ & $57.6 \pm 0.54$ & $1.9 \pm 0.02$ & $84.3 \pm 1.81$ \\
\hline Hellen & $10.6 \pm 0.45^{a}$ & $12.7 \pm 0.26^{b}$ & $87.3 \pm 0.26^{a}$ & $57.7 \pm 0.56$ & $1.9 \pm 0.02$ & $82.9 \pm 1.60$ \\
\hline Trinova & $10.3 \pm 0.46^{b}$ & $13.1 \pm 0.21^{b}$ & $87.0 \pm 0.21^{a}$ & $57.4 \pm 0.43$ & $1.9 \pm 0.01$ & $82.6 \pm 1.11$ \\
\hline Mean & 10.4 & 13.1 & 86.9 & 57.6 & 1.9 & 83.3 \\
\hline$p$-value & $\star *$ & $\star *$ & $\star \star$ & ns & ns & ns \\
\hline \multicolumn{7}{|c|}{ Cutting rank } \\
\hline $1 s t$ & $10.1 \pm 0.36^{b}$ & $13.8 \pm 0.19^{a}$ & $86.3 \pm 0.19^{b}$ & $57.0 \pm 0.49$ & $1.9 \pm 0.02^{a}$ & $83.8 \pm 1.52$ \\
\hline 2nd & $10.7 \pm 0.35^{a}$ & $12.5 \pm 0.16^{b}$ & $87.5 \pm 0.16^{a}$ & $58.2 \pm 0.29$ & $1.8 \pm 0.01^{b}$ & $82.8 \pm 0.91$ \\
\hline Mean & 10.4 & 13.1 & 86.9 & 57.6 & 1.9 & 83.3 \\
\hline p-value & $\star \star$ & $\star \star$ & $\star \star$ & ns & * & ns \\
\hline
\end{tabular}

$\mathrm{CP}$, crude protein; OM, organic matter; DMD, dry matter digestibility; DMI, dry matter intake; RFV, relative feed value; ns, non-significant.

a-e Mean values with different superscripts have significant differences. ${ }^{*} p<0.01 ; * p<0.05$.

doses was in the opposite direction of the trend of change in LA content. The AA content of silage DM increased from $1.14 \%$ at $\mathrm{N}_{0}$ to $1.66 \%$ at $\mathrm{N}_{200}$ (Table 4). Cultivar had no effect on AA content but AA content of the first cut (1.53\% DM)

Table 4. Effects of $\mathrm{N}$ doses, cultivars and cutting rank on some silage products and LA/AA

\begin{tabular}{|c|c|c|c|}
\hline Items & $\begin{array}{l}\text { Lactic acid } \\
\text { (\% DM) }\end{array}$ & $\begin{array}{l}\text { Acetic acid } \\
\text { (\% DM) }\end{array}$ & LA/AA \\
\hline \multicolumn{4}{|c|}{ N Doses (kg/ha) } \\
\hline $\mathrm{N}_{0}$ & $4.18 \pm 0.11^{\mathrm{a}}$ & $1.14 \pm 0.04^{\mathrm{e}}$ & $3.83 \pm 0.25^{\mathrm{a}}$ \\
\hline $\mathrm{N}_{50}$ & $3.73 \pm 0.09^{b}$ & $1.27 \pm 0.04^{d}$ & $2.99 \pm 0.15^{b}$ \\
\hline $\mathrm{N}_{100}$ & $3.48 \pm 0.06^{c}$ & $1.44 \pm 0.03^{c}$ & $2.43 \pm 0.07^{c}$ \\
\hline $\mathrm{N}_{150}$ & $3.40 \pm 0.05^{c}$ & $1.56 \pm 0.04^{b}$ & $2.20 \pm 0.07^{c}$ \\
\hline $\mathrm{N}_{200}$ & $3.13 \pm 0.05^{d}$ & $1.66 \pm 0.04^{\mathrm{a}}$ & $1.91 \pm 0.07^{d}$ \\
\hline Mean & 3.58 & 1.41 & 2.67 \\
\hline p-value & $\star \star$ & * & $\star \star$ \\
\hline \multicolumn{4}{|l|}{ Cultivars } \\
\hline Devis & $3.46 \pm 0.10^{b}$ & $1.41 \pm 0.05$ & $2.56 \pm 0.19^{b}$ \\
\hline Hellen & $3.64 \pm 0.08^{a}$ & $1.43 \pm 0.04$ & $2.70 \pm 0.13^{\mathrm{ab}}$ \\
\hline Trinova & $3.65 \pm 0.08^{a}$ & $1.41 \pm 0.05$ & $2.76 \pm 0.17^{a}$ \\
\hline Mean & 3.58 & 1.42 & 2.67 \\
\hline p-value & $\star \star$ & ns & * \\
\hline \multicolumn{4}{|c|}{ Cutting rank } \\
\hline $1 \mathrm{st}$ & $3.36 \pm 0.04^{b}$ & $1.53 \pm 0.03^{\mathrm{a}}$ & $2.25 \pm 0.07^{b}$ \\
\hline 2nd & $3.80 \pm 0.08^{\mathrm{a}}$ & $1.30 \pm 0.03^{b}$ & $3.09 \pm 0.15^{a}$ \\
\hline Mean & 3.58 & 1.42 & 2.67 \\
\hline$p$-valure & $\star \star$ & $\star \star$ & $\star \star$ \\
\hline
\end{tabular}

DM, dry matter; LA/AA, lactic acid/acetic acid; ns, non-significant

${ }^{a-e}$ Mean values with different superscripts have significant differences. ** $p<0.01 ;{ }^{*} p<0.05$. was higher $(\mathrm{p}<0.01)$ than that observed in the second cut (1.30\%).

\section{DISCUSSION}

According to the results of the research, it can be said that forage quality characteristics (CP, NDF, ADF, DMD, DMI, and RFV) not related to ensiling were positively affected by increasing nitrogen doses, but characteristics related to silage (DM content, $\mathrm{pH}, \mathrm{NH}_{3}-\mathrm{N}, \mathrm{LA}$ content, $\mathrm{AA}$ content) are negatively affected by increasing nitrogen doses.

Increasing the dose of nitrogen to $\mathrm{N}_{50}, \mathrm{~N}_{100}, \mathrm{~N}_{150}$, and $\mathrm{N}_{200}$ $\mathrm{kg} / \mathrm{ha}$ resulted in an increase of $21.8 \%, 58.5 \%, 77.3 \%$, and $86.9 \%$ in CP content compared to the control, respectively. It can be said that the protein content of annual ryegrass increases in response to nitrogen application [18]. Similarly, it has been reported by other researchers that the protein content of annual ryegrass increases in response to nitrogen application [19]. Some researchers have reported higher \%CP values for annual ryegrass than ours while other researchers have reported similar values to ours $[19,20,21]$. One of the main reasons for these differences may be that the harvest to obtain dry herbage is done at an earlier stage of plant maturity than the harvest for silage. Consistent with our findings, previous researchers determined that the protein contents of annual ryegrass silages varied between $6.33 \%$ and $14.54 \%$ $[22,23]$. Since protein is a major cost in supplements for livestock, the total amount of protein produced per unit area is one of the most important quality characteristics [24-26]. 
Therefore, nitrogen fertilization at the appropriate dose can be an effective tool to increase the protein content of lowprotein grasses to meet the protein needs of animals. It was also determined that the NDF, ADF, DMD, DMI, and RFV values of the silages were positively affected by the increasing nitrogen doses. Our findings are inconsistent with some previous research results, which reported that these values increased or did not change with increasing nitrogen doses $[18,27,28]$. Pinho et al [29] reported that in terms of NDF, the response of pearl millet to nitrogen doses varies depending on genotypes. Cinar et al [22] reported that the effect on RFV of $\mathrm{N}$ doses changes depending on years. The effect of fertilization rate on grass degradability characteristics is not consistent [30].

Dry matter contents of annual ryegrass silages were decreased with increased $\mathrm{N}$ doses. With low $\mathrm{N}$ fertilization, DM contents of grasses increase [27] and this change in silage raw material is reflected in silage [29]. However, low DM content has a negative effect on the ensiling ability of the plant material. Dry matter content of forage crops at harvest is one of the most important factors for successful ensilage $[31,32]$. According to Castle and Watson [33] a minimal DM content of $247 \mathrm{~g} / \mathrm{kg}$ is required for silage production. Therefore, excessive nitrogen fertilization in forage crops to be silage may pose a risk, especially in early mowing. The amount of LA produced by LA bacteria during silage fermentation is usually the acid concentration, and during the LA fermentation it is the acid that causes the greatest decrease in $\mathrm{pH}, 10$ to 12 times stronger than AA found in silages [34]. The increase in $\mathrm{pH}$, the amount of $\mathrm{NH}_{3}-\mathrm{N}$ and $\mathrm{AA}$ content due to the increase in nitrogen dose and the decrease in and LA content support this situation. Consistent with our results, Lv et al [4] reported that although high nitrogen application for ryegrass silage is an effective application in terms of nutrient content of silage, it may reduce the silage fermentation quality in silage, especially because it causes low DM content and high $\mathrm{NH}_{3}-\mathrm{N}$ content.

In the present study, DM content increased with advancement in cutting rank. This situation may be the result of high temperatures in the second cutting time. Similar differences in DM content at different cutting periods were reported by Valk et al [30] and Baldinger et al [23]. Baldinger et al [23] reported $\mathrm{pH}$ values close to our values while they determined higher LA values than our LA values for annual ryegrass. In the second cutting, better values were obtained in terms of ensiling properties $\left(\mathrm{pH}, \mathrm{NH}_{3}-\mathrm{N}, \mathrm{LA}\right.$, and $\mathrm{AA}$ ) compared to the first cutting. This situation might be explained by increasing DM content [35]. Also, an increase in protein content was detected in the second cutting. This increase may have been due to nitrogen applied after first harvest. Also, Garcia del Moral et al [36] emphasized that forage CP content was negatively related to forage yield (data not shown) due to available $\mathrm{N}$ distributing in a greater volume of plant tissue.

Generally, quality parameters of the cultivars tested were similar. CP content and OM content of cv. Hellen were higher than for cvs Devis and Trinova. Our findings agree with Lale and Kökten [37], who reported that CP content changed depending on the cultivars. However, their calculated $\mathrm{CP}$ content for annual ryegrass was higher than our values. In another study, Colak and Sancak [20] reported that no significant difference in $\mathrm{CP}$ of annual ryegrass cultivars. In addition, Costa et al [38] determined that the CP content of varieties varied significantly depending on the plant growing stage. In our study LA content of cv. Devis was lower than cv. Hellen and $\mathrm{cv}$. Trinova. There was no difference among cultivars in terms of other quality parameters examined. Our findings are consistent with Costa et al [38], who reported that the $\mathrm{ADF}$ and NDF contents of annual ryegrass harvested in the generative period were close to each other.

\section{IMPLICATIONS}

Research results have shown that increasing nitrogen doses positively affect the chemical composition of annual ryegrass silage. Especially the significant increase in protein content was remarkable. However, silage fermentation properties were adversely affected by the increasing nitrogen dose. When these two data are evaluated together, $150 \mathrm{~kg} / \mathrm{ha}$ nitrogen dose can be recommended for annual ryegrass harvested in full blooming stage. Cultivars tested in this study gave the similar results in terms of nutritive value and silage fermentation quality. In terms of silage fermentation values, especially considering the dry matter content and $\mathrm{pH}$ values, it can be said that the annual ryegrass produced from the second cutting is the better silage material.

\section{CONFLICT OF INTEREST}

We certify that there is no conflict of interest with any financial organization regarding the material discussed in the manuscript.

\section{FUNDING}

The authors received no financial support for this article.

\section{ACKNOWLEDGMENTS}

We would like to thank Hatay Mustafa Kemal University for which we have used the infrastructure facilities within the scope of this study.

\section{REFERENCES}


1. Shao T, Ohba N, Shimojo M, Masuda Y. Dynamics of early fermentation of Italian ryegrass (Lolium multiflorum Lam.) silage. Asian-Australas J Anim Sci 2002;15:1606-10. https:// doi.org/10.5713/ajas.2002.1606

2. Shao T, Zhang ZX, Shimojo M, Wang T, Masuda Y. Comparison of fermentation characteristics of Italian ryegrass (Lolium multiflorum Lam.) and Guineagrass (Panicum maximum Jacq.) during the early stage of ensiling. Asian-Australas J Anim Sci 2005;18:1727-34. https://doi.org/10.5713/ajas.2005. 1727

3. Ertekin İ, Atış, İ, Yllmaz Ş. The effects of different organic fertilizers on forage yield and quality of some vetch species. MKU J Agric Sci 2020;25:243-55. https://doi.org/10.37908/ mkutbd.739805

4. Lv R, El-Sabagh M, Obitsu T, Sugino T, Kurokawa Y, Kawamura $\mathrm{K}$. Effects of nitrogen fertilizer and harvesting stage on photosynthetic pigments and phytol contents of Italian ryegrass silage. Anim Sci J 2017;88:1513-22. https://doi.org/10.1111/ asj. 12810

5. Lefsrud MG, Sorochan JC, Kopsell DA, Scott Mcelroy J. Pigment concentrations among heat-tolerant turfgrasses. HortScience 2010;45:650-3. https://doi.org/10.21273/HORTSCI. 45.4.650

6. Simić A, Vučković S, Kresović M, Vrbničanin S, Božić D. Changes of crude protein content in Italian ryegrass influenced by spring nitrogen pplication. Biotechnol Anim Husb 2009;25:1171-9.

7. Kunelius T, Boswall P. Producing annual ryegrasses for pasture, silage and seed. Canada: Agriculture and Forestry Farm Extension Services; 2009.

8. Yu-lan LV, Wang YQ, Yang B, Yang Y, Zhang XF. Effects of nitrogen fertilizing on the leaf chlorophyll content and fresh forage yield of (Lolium multiflorum cv. Tetragold). Baoshan, China: Tropical and Subtropical Cash Crops Institute, Yunnan Academy of Agricultural Sciences; 2013.

9. Pavinato PS, Restelatto R, Sartor LR, Paris W. Production and nutritive value of ryegrass (cv. Barjumbo) under nitrogen fertilization. Rev Ciênc Agron 2014;45:230-7. https:/doi.org/ 10.1590/S1806-66902014000200002

10. Ertekin İ, Kızılşimşek M. Effects of lactic acid bacteria inoculation in pre-harvesting period on fermentation and feed quality properties of alfalfa silage. Asian-Australas J Anim Sci 2020;33:245-53. https://doi.org/10.5713/ajas.18.0801

11. Dubois M, Gilles KA, Hamilton JK, Rebers PA, Smith F. Colorimetric method for determination of sugars and related substances. Anal Chem 1956;28:350-6.

12. Association of Official Analytical Chemists (AOAC). Official method of analysis. 15th ed., Washington, DC, USA: Association of Official Analytical Chemists; 1990. pp. 66-8.

13. Association of Official Analytical Chemists (AOAC). In: Hortwitz W, Latimer Jr. GW, editors, Official methods of analysis of AOAC Int. 18th ed. Gaithersburg, MD, USA:
AOAC Int.; 2007.

14. Robertson JB, Van Soest PJ. Dietary fibre estimation in concentrate feedstuffs. J Anim Sci 1977;45(Suppl.):254. (Abstr.)

15. Blümmel M, Makkar HPS, Becker K. In vitro gas productiona technique revisied. J Anim Physiol Anim Nutr 1997;77:2434. https://doi.org/10.1111/j.1439-0396.1997.tb00734.x

16. Quiros ARB, Yusty MAL, Hernandez JL. HPLC analysis of organic acids using a novel stationary phase. Talanta 2009; 78:643-6. https://doi.org/10.1016/j.talanta.2008.11.013

17. Van Dyke NJ, Anderson PM. Interpreting a forage analysis. Alabama Cooperative Extension, Circular 2002;ANR-890.

18. Heeren JAH, Podesta SC, Hatew B, et al. Rumen degradation characteristics of ryegrass herbage and ryegrass silage are affected by interactions between stage of maturity and nitrogen fertilisation rate. Anim Prod Sci 2014;54:1263-7. https://doi. org/10.1071/AN14259

19. Kusvuran A. The effects of different nitrogen doses on herbage and seed yields of annual ryegrass (Lolium multiflorum cv. caramba). Afr J Biotechnol 2011;10:12916-24. https://doi. org/10.5897/AJB11.3049

20. Colak E, Sancak C. The effect of nitrogen fertilizer doses on herbage quality of Italian ryegrass (Lolium italicum L.) cultivars. Mediterr Agric Sci 2017;30:245-51. https://doi.org/ 10.29136/mediterranean.359996

21. Bora SS, Sharma KK, Borah K, Saud RK, Borgohain L. Effect of nitrogen levels and seed rate on quality of ryegrass (Lolium multiflorum) in Assam. Forage Res 2020;46:54-7.

22. Cinar S, Ozkurt M, Cetin R. Effects of nitrogen fertilization rates on forage yield and quality of annual ryegrass (Lolium multiflorum L.) in Central Black Sea climatic zone in Turkey. Appl Ecol Environ Res 2020;8:417-32. https://doi.org/10. 15666/aeer/1801_417432

23. Baldinger L, Baumung R, Zollitsch W, Knaus WF. Italian ryegrass silage in winter feeding of organic dairy cows: forage intake, milk yield and composition. J Sci Food Agric 2011; 91:435-42. https://doi.org/10.1002/jsfa.4203

24. Assefa G, Ledin I. Effect of variety, soil type and fertiliser on the establishment, growth, forage yield, quality and voluntary intake by cattle of oats and vetches cultivated in pure stands and mixtures. Anim Feed Sci Technol 2001;92:95111. https://doi.org/10.1016/S0377-8401(01)00242-5

25. Atis I, Kokten K, Hatipoglu R, Yilmaz S, Atak M, Can E. Plant density and mixture ratio effects on the competition between common vetch and wheat. Aust J Crop Sci 2012;6: 498-505.

26. Atis I, Konuskan O, Duru M, Gozubenli H, Yilmaz S. Effect of harvesting time on yield, composition and forage quality of some forage sorghum cultivars. Int J Agric Biol 2012;14: 879-86.

27. Peyraud JL, Astigarraga L, Faverdin P. Digestion of fresh perennial ryegrass fertilized at two levels of nitrogen by lactating dairy cows. Anim Feed Sci Technol 1997;64:155- 
71. https://doi.org/10.1016/S0377-8401(96)01056-5

28. Astigarraga L, Peyraud JL, Delaby L. Effect of nitrogen fertiliser rate and protein supplementation on the herbage intake and the nitrogen balance of grazing dairy cows. Anim Res 2002; 51:279-93. https://doi.org/10.1051/animres:2002022

29. Pinho RMA, Santos EM, Campos FS, et al. Silages of pearl millet submitted to nitrogen fertilization. Cienc Rural 2014;44: 918-24.

30. Valk H, Kappers IE, Tamminga S. In sacco degradation characteristics of organic matter, neutral detergent fibre and crude protein of fresh grass fertilized with different amounts of nitrogen. Anim Feed Sci Technol 1996;63:63-87. https://doi. org/10.1016/S0377-8401(96)01024-3

31. Miron J, Solomon R, Adin G, et al. Effects of harvest stage and re-growth on yield, composition, ensilage and in vitro digestibility of new forage sorghum varieties. J Sci Food Agric 2006;86:140-7. https://doi.org/10.1002/jsfa.2269

32. Carmi A, Aharoni Y, Edelstein M, et al. Effects of irrigation and plant density on yield, composition and in vitro digestibility of a new forage sorghum variety, Tal, at two maturity stages. Anim Feed Sci Technol 2006;131:120-33. https://doi. org/10.1016/j.anifeedsci.2006.02.005

33. Castle ME, Watson JN. The relationship between the DM content of herbage for silage making and effluent production. J Br Grassl Soc 1973;28:135-8. https://doi.org/10.1111/ j. 1365-2494.1973.tb00734.x

34. Kung Jr L, Shaver RD, Grant RJ, Schmidt RJ. Silage review: Interpretation of chemical, microbial, and organoleptic components of silages. J Dairy Sci 2018;101:4020-33. https:// doi.org/10.3168/jds.2017-13909

35. Atis I, Duru M, Konuskan O, Gozubenli H. Effects of plant maturity stage on silage quality of some silage sorghum cultivars. J Food Agric Environ 2013;11:534-7.

36. Garcia del Moral LF, Boujenna A, Yanez JA, Ramos JM. Forage production, grain yield, and protein content in dualpurpose triticale grown for both grain and forage. Agron J 1995;87:902-8. https://doi.org/10.2134/ agronj1995.0002196 2008700050021x

37. Lale V, Kökten K. Determination of herbage yield and quality of some Italian ryegrass (Lolium multiflorum Lam.) varieties in Bingol conditions. Trk J Nat Sci 2020;9(Spec Is):46-50. https://doi.org/10.46810/tdfd.762718

38. Costa OAD, Ferreira OGL, da Silva JLS, et al. Yield, structural composition and nutritive characteristics of ryegrass cultivars used to haymaking in lowland soils. Biosci J 2018; 34:1232-8. https://doi.org/10.14393/BJ-v34n5a2018-39405 